\title{
PENGARUH PEMBERIAN EDUKASI MELALUI VIDEO TERHADAP KESIAPAN PULANG PASIEN DENGAN PENYAKIT JANTUNG KORONER DI RUMAH SAKIT DAERAH (RSD) MANGUSADA BADUNG
}

\author{
Ni Luh Suari Sasmita Dewi ${ }^{1}$ I Made Dwie Pradnya Susila, ${ }^{1,}$, Ni Komang Purwaningsih ${ }^{1}$ \\ STIKES Bina Usada Bali ${ }^{1}$ \\ e-mail: dwiepradnya@gmail.com*
}

\begin{abstract}
Health education is defined as the process by which health professionals provide information to patients that will change their health behavior or improve their health status. Properly targeted health education can lead to reduce hospitalizations. Educational interventions in heart care have been shown to increase physical activity and lead to healthy dietary habits and smoking cessation. One of the promotional methods that can be used to prepare home readiness of patients is audio visual media. This study aimed at determining the effect of video education on home readiness of patients with coronary heart disease in Mangusada Badung Regional Hospital. This study was a quasi-experimental study with a nonequivalent control group design. Home readiness of patients was analyzed using RHDS questionnaire. The control group (conventional lecture method) in this study was a group without video education, the treatment group had been given video education with 36 samples of each group using a systematic sampling method. Data analysis used t paired sample test and Man Whitney test. Based on MannWhitney $U$ test with a confidence level of $95 \%$, the results obtained $P$-value, $=0.000$ with $Z$ value $=-7.215$ therefore it can be concluded that providing video education media had a greater effect than providing lecture media education on home readiness of patients with coronary heart disease.
\end{abstract}

Keywords: health education, video media, RHDS

\begin{abstract}
ABSTRAK
Pendidikan kesehatan didefinisikan sebagai proses dimana profesional kesehatan memberikan informasi kepada pasien yang akan mengubah perilaku kesehatan mereka atau meningkatkan status kesehatan mereka. Pendidikan kesehatan yang tepat pada sasaran dapat menyebabkan berkurangnya rawat inap. Intervensi pendidikan dalam perawatan jantung terbukti meningkatkan aktivitas fisik, dan menyebabkan kebiasaan diet sehat dan berhenti merokok. Salah satu metode promosi yang bisa digunakan untuk mempersiapkan pasien pulang yaitu dengan media audio visual. Penelitian ini bertujuan untuk mengetahui pengaruh pemberian edukasi melalui video terhadap kesiapan pulang pasien dengan penyakit jantung koroner di Rumah Sakit Daerah (RSD) Mangusada Badung. Penelitian ini merupakan penelitian quasi eksperimen dengan rancangan nonequivalent control group design. Kesiapan pasien pulang dianalisis menggunakan kuesioner RHDS. Kelompok kontrol (metode konvensional ceramah) dalam penelitian ini adalah kelompok tanpa pemberian edukasi video, kelompok perlakuan diberikan edukasi video dengan jumlah sample masing masing kelompok 36 sampel dengan metode sampling sistematis. Data analisis mengunakan dengan uji t paired sample test dan Man Whitney. Berdasarkan uji Mann-Whitney $U$ dengan tingkat kepercayaan 95\% didapatkan hasil $P$-value,$=0.000$ dengan nilai $\mathrm{Z}=-7.215$ sehingga dapat disimpulkan pemberian edukasi media video memiliki pengaruh yang lebih besar dibandingkan dengan pemberian edukasi media ceramah terhadap kesiapan pasien pulang pasien dengan penyakit jantung koroner.
\end{abstract}

Kata kunci: pendidikan kesehatan, media video, $R H D S$ 


\section{PENDAHULUAN}

Penyakit jantung koroner (PJK) atau di kenal dengan Coronary Artery Disease (CAD) merupakan suatu penyakit yang terjadi ketika arteri yang mensuplai darah untuk dinding jantung mengalami pengerasan dan penyempitan (Fakultas Kedokteran Universitas Hasanuddin, 2017). World Health Organization (WHO) menyebutkan bahwa penyakit jantung koroner (PJK) menjadi salah satu masalah kesehatan dalam sitem kardiovaskular yang jumlahnya meningkat cepat dengan angka kematian 6,7 juta kasus (WHO, 2013) Perhitungan WHO yang memperkirakan pada tahun 2020 mendatang, penyakit kardiovaskuler akan menyumbang sekitar $25 \%$ dari angka kematian dan mengalami peningkatan khususnya di negaranegara berkembang, salah satu diantaranya berada di Asia Tenggara. Angka kematian yang disebabkan oleh PJK mencapai 1,8 juta kasus pada tahun 2014, yang artinya PJK menjadi penyakit yang mematikan di kawasan Asia Tenggara salah satu negaranya adalah Indonesia (WHO, 2013).

Angka kematian yang disebabkan oleh PJK di Indonesia cukup tinggi mencapai 1,25 juta jiwa jika populasi penduduk Indonesia 250 juta jiwa (Kementrian.Kesehatan, 2011). Berdasarkan data Riset Kesehatan Dasar (Riskesdas) tahun 2018, angka kejadian penyakit jantung dan pembuluh darah semakin meningkat dari tahun ke tahun. Setidaknya, 15 dari 1000 orang, atau sekitar 2.784.064 individu di Indonesia menderita penyakit jantung.

Berdasarkan data yang diperoleh dari SIM RSD Mangusada jumlah pasien yang dirawat dengan diagnosa penyakit jantung koroner pada tahun 2019 adalah sebanyak 216 orang, yang dirawat di ruang ICCU sebanyak 108 orang, sedangkan angka rawat kembali dengan penyakit yang sama dalam satu tahun yaitu sebesar $50 \%$ dengan jumlah kali rawat mencapai lima kali rawat kembali dalam rentang waktu tersebut.

Menurut penelitian Desai \& Stevenson, (2012), pasien dengan penyakit jantung koroner masuk rawat inap kembali ke rumah sakit dalam waktu enam bulan setelah pulang dari rumah sakit, salah satu faktor yang mempengaruhinya adalah menurunnya ketaatan terapi dan kurangnya informasi kesehatan yang diperoleh pasien serta kurang maximalnya pemberian asuhan keperawatan yang diberikan untuk mempersiapkan pasien pulang.

Saat pemberian asuhan keperawatan dengan penyakit jantung koroner perawat mempunyai peran penting dalam pelaksanaan kesiapan pasien pulang pasien, oleh karena itu diperlukan komunikasi yang baik dan terarah yang dapat dimengerti dan berguna dalam proses perawatan di rumah. Selama ini peran perawat dalam pelaksanaan perencanaan pulang pasien belum optimal, peran keperawatan terbatas pada rutinitas saja yaitu informasi kontrol ulang, keluarga atau pasien tidak dibantu dalam keperawatan kesehatan di rumah, tidak diberikan konseling kesehatan atau penyuluhan, dan tidak dibantu tentang pelayanan komunitas yang dibutuhkan saat keluar rumah sakit dapat mengakibatkan kunjungan kembali ke ruang gawat darurat dengan masalah minor dalam waktu 24 jam sampai 48 jam (Nursalam, 2013).

Menurut penelitian yang pernah dilakukan Rofi'i (2013) menunjukan pelaksanan kesiapan pasien pulang $1,7 \%$ diberikan 24 jam setelah pasien masuk dan $15 \%$ diberikan dalam waktu 72 jam setelah pasien masuk Rumah Sakit, hal tersebut mengakibatkan keterlambatan dalam proses perencanaan pulang pasien dan kerugian pembiayaan biaya karena tidak sejak dini dilakukan dan dapat menikatkan lama hari perawatan. Hasil penelitian yang dilakukan Hardianti \& Asri, (2017) tentang "Evaluasi Pelaksanaan Prencaan Psien Plang di Rumah Sakit Yogyakarta" menunjukkan bahwa perawat kurang memahami tentang kesiapan pasien pulang dan sikap serta pengendalian emosi perawat dalam memberikan pelayanan didapatkan $36,4 \%$ masih menyatakan kurang baik. Rumah sakit tidak memiliki SOP khusus pelaksanaan dan form perencaan pasien pulang.

Berdasarkan studi pendaluhuan yang dilakukan di ruang rawat inap RSD Mangusada didapatkan hasil dari sembilan pasien yang dilakukan pengukuran kesiapan pasien pulang didapatkan hanya satu orang pasien yang kesiapan paling tinggi, dua orang dengan kesiapan rendah, enam orang dengan kesiapan sedang.

Pendidikan kesehatan didefinisikan sebagai proses dimana profesional kesehatan memberikan informasi kepada pasien yang akan mengubah perilaku kesehatan mereka atau meningkatkan status kesehatan mereka (Notoatmodjo, 2007). Pendidikan kesehatan yang tepat pada sasaran dapat menyebabkan berkurangnya rawat inap dan penurunan biaya terkait, baik untuk pasien dan rumah sakit (Susanti, 2017). Intervensi pendidikan dalam perawatan jantung telah terbukti meningkatkan aktivitas fisik, dan menyebabkan kebiasaan diet sehat dan berhenti merokok, meskipun ada terkait peningkatan respon terhadap gejala jantung, kepatuhan pengobatan atau kesejahteraan psikososial (Serawati, 2017).

Salah satu metode promosi yang bisa digunakan untuk mempersiapkan pasien pulang yaitu dengan media audio visual, media ini merupakan salah satu media promosi kesehatan yang digunakan sebagai media pendidikan kesehatan dengan unsur gerak, suara dan gambar yang terpadu menjadi satu (Notoatmodjo, 2007). Menurut Abu Abed, Himmel, Vormfelde, \& Koschack, (2014), video mampu merebut $94 \%$ saluran masuknya pesan atau informasi ke dalam jiwa manusia melalui mata dan telinga serta mampu untuk membuat orang pada umumnya mengingat $50 \%$ dari apa yang mereka lihat dan dengar dari tayangan program. Pesan yang disampaikan melalui media video dapat mempengaruhi emosi yang kuat dan juga dapat mencapai hasil cepat yang tidak dimiliki oleh media lain (Fiore- silfvast et al., 2013). Menurut Cheppy (2007), media video pembelajaran sebagai media edukasi bertujuan untuk memperjelas dan mempermudah penyampaian pesan agar tidak terlalu 


\section{Vol. 16 No.2 Mei - Agustus 2021}

verbalistis, serta mengatasi keterbatasan waktu, ruang dan daya indera pemberi dan penerima informasi.

\section{METODE}

Penelitian ini merupakan penelitian quasi eksperimen dengan rancangan nonequivalent control group design. Kelompok kontrol (metode konvensional ceramah) dalam penelitian ini adalah kelompok tanpa pemberian edukasi video, kelompok perlakuan akan diberikan edukasi video. Responden pada kelompok kontrol akan dilakukan pengukuran kesiapan pulang sebelum dan sesudah diberikan terapi konvensional. Pada kelompok perlakuan responden juga akan dilakukan pengukuran kesiapan pulang sebelum maupun sesudah diberikan edukasi video.

Responden dalam penelitian ini adalah semua pasien penyakit jantung di ruang rawat inap ICCU dan Oleg RSD Mangusada. yang berjumlah 36 orang untuk masing-masing kelompok diambil berdasarkan sampling sistematis. Kesiapan pasien pulang dianalisis menggunakan kuesioner RHDS. Kelompok kontrol (metode konvensional ceramah) dalam penelitian ini adalah kelompok tanpa pemberian edukasi video, kelompok perlakuan diberikan edukasi video. Data analisis mengunakan dengan uji t paired sample test dan Man Whitney.

\section{HASIL}

\section{Karakteristik Responden Berdasarkan Usia}

Tabel 1

Responden Berdasarkan Usia

\begin{tabular}{|c|c|c|c|c|}
\hline \multicolumn{5}{|c|}{ Kelompok } \\
\hline & & Ceramah & Video & Total \\
\hline \multirow[t]{8}{*}{ Usia } & $26-30$ & 5 & 2 & 7 \\
\hline & $31-35$ & 5 & 6 & 11 \\
\hline & $36-40$ & 5 & 5 & 10 \\
\hline & $41-45$ & 8 & 6 & 14 \\
\hline & $46-50$ & 7 & 7 & 14 \\
\hline & $51-55$ & 4 & 7 & 11 \\
\hline & $56-60$ & 1 & 2 & 3 \\
\hline & $61-65$ & 1 & 1 & 2 \\
\hline Total & & 36 & 36 & 72 \\
\hline
\end{tabular}

Pada tabel diatas terlihat pada kelompok metode ceramah sebanyak 8 responden usia 41-45 tahun. Pada kelompok edukasi video penderita penyakit jantung koroner usia 46 - 50 dan 51-55 tahun sebesar 7 responden.

\section{Karakteristik Responden Berdasarkan Jenis Kelamin}

Tabel 2

Responden Berdasarkan Jenis Kelamin

\begin{tabular}{|c|c|c|c|c|}
\hline \multicolumn{5}{|c|}{ Kelompok } \\
\hline & & Ceramah & Video & Total \\
\hline \multirow[t]{2}{*}{ Jenis Kelamin } & Perempuan & 13 & 11 & 24 \\
\hline & Laki-Laki & 23 & 25 & 48 \\
\hline Total & & 36 & 36 & 72 \\
\hline
\end{tabular}

Terlihat pada tabel diatas, sebesar 23 responden pada kelompok metode ceramah berjenis kelamin laki - laki dan pada kelompok metode edukasi video responden paling tinggi yaitu 25 responden berjenis kelamin laki laki.

\section{Karakterristik Responden Berdasarkan Riwayat Penyakit}

Tabel 3

Reponden Berdasarkan Riwayat Penyakit

\begin{tabular}{|c|c|c|c|c|}
\hline \multicolumn{5}{|c|}{ Kelompok } \\
\hline & & Ceramah & Video & Total \\
\hline \multirow[t]{3}{*}{ Riwayat penyakit } & Diabetes & 16 & 10 & 26 \\
\hline & Hipertensi & 11 & 16 & 27 \\
\hline & Lain-Lain & 9 & 10 & 19 \\
\hline Total & & 36 & 36 & 72 \\
\hline
\end{tabular}

Pada tabel diatas, kelompok metode ceramah penderita diabetes yang mengalami penyakit jantung koroner sebesar 16 dan penyakit hipertensi sebesar 11 sedangkan pada kelompok edukasi media video 16 responden penderita penyakit jantung korener menderita hipertensi.

\section{Karakteristik Responden Berdasarkan Dirawat Kembali}

Tabel 4

Responden Berdasarkan Dirawat Kembali

\begin{tabular}{lcccc}
\hline \multicolumn{5}{c}{ Kelompok } \\
\hline \multirow{4}{*}{ Dirawat Kembali } & $<3$ bulan & 8 & 9 & 17 \\
\cline { 2 - 5 } & $>3$ bulan & 28 & 27 & 55 \\
\hline Total & & 36 & 36 & 72 \\
\hline
\end{tabular}

Terlihat pada tabel diatas, kelompok medote ceramah sebesar 28 responden mengalami dirawat kembali lebih dari 3 bulan, sedangkan pada metode edukasi video yang mengalami rawat inapkembali lebih dari 3 bulan sebanyak 27 responden. 


\section{Nilai Kesiapan Pulang Pasien dengan Menggunakan Edukasi Ceramah}

Tabel 5

Nilai Kesiapan Pulang Pasien sebelum Diberikan Edukasi Media Ceramah

\begin{tabular}{cccc}
\hline Nilai & $N$ & $\%$ & Cumulative Percent \\
\hline 45 & 3 & 8.3 & 8.3 \\
\hline 46 & 5 & 13.9 & 22.2 \\
\hline 47 & 8 & 22.2 & 44.4 \\
\hline 48 & 9 & 25.0 & 69.4 \\
\hline 49 & 8 & 22.2 & 91.7 \\
\hline 50 & 1 & 2.8 & 94.4 \\
\hline 51 & 1 & 2.8 & 97.2 \\
\hline 52 & 1 & 2.8 & 100.0 \\
\hline
\end{tabular}

Nilai tertinggi kesiapan pulang sebelum diberikan edukasi media ceramah yaitu 1 orang responden dengan nilai 52 dan nilai terendah 3 orang responden dengan nilai 45 .

Tabel 6

Nilai Kesiapan Pulang Pasien setelah Diberikan Edukasi Media Ceramah

\begin{tabular}{cccc}
\hline Nilai & $N$ & $\%$ & Cumulative Percent \\
\hline 50 & 4 & 11.1 & 11.1 \\
\hline 51 & 3 & 8.3 & 19.4 \\
\hline 52 & 1 & 2.8 & 22.2 \\
\hline 53 & 4 & 11.1 & 33.3 \\
\hline 54 & 6 & 16.7 & 50.0 \\
\hline 55 & 6 & 16.7 & 66.7 \\
\hline 56 & 4 & 11.1 & 77.8 \\
\hline 57 & 4 & 11.1 & 88.9 \\
\hline 58 & 3 & 8.3 & 97.2 \\
\hline 59 & 1 & 2.8 & 100.0 \\
\hline
\end{tabular}

Untuk nilai tertinggi setelah diberikan edukasi media ceramah yaitu 1 orang respon dengan nilai 59 dan nilai terendah setelah diberikan edukasi media ceramah yaitu 50 sebanyak 4 responden.

\section{Nilai Kesiapan Pulang pasien dengan Menggunakan Edukasi Video}

Tabel 7

Nilai Kesiapan Pulang Pasien Sebelum Diberikan Edukasi Media Video

\begin{tabular}{cccc}
\hline Nilai & $N$ & $\%$ & Cumulative Percent \\
\hline 43 & 1 & 2.8 & 2.8 \\
\hline 44 & 4 & 11.1 & 13.9 \\
\hline 45 & 5 & 13.9 & 27.8 \\
\hline 46 & 7 & 19.4 & 47.2 \\
\hline 47 & 7 & 19.4 & 66.7 \\
\hline 48 & 4 & 11.1 & 77.8 \\
\hline 49 & 5 & 13.9 & 91.7 \\
\hline
\end{tabular}

\begin{tabular}{llll}
\hline 50 & 3 & 8.3 & 100.0 \\
\hline
\end{tabular}

Terlihat pada tabel diatas nilai tertinggi kesiapan pulang pasien dengan penyakit jantung koroner pada kelompok metode video yaitu 3 responden mendapatkan nilai 50 dan nilai terendah sebelum diberikan edukasi video sebanyak 1 responden mendapatkan 43 .

Tabel 8

Nilai Kesiapan Pulang Pasien setelah Diberikan Edukasi Media Video

\begin{tabular}{cccc}
\hline Nilai & $\mathrm{N}$ & $\%$ & Cumulative Percent \\
\hline 58 & 2 & 5.6 & 5.6 \\
\hline 59 & 3 & 8.3 & 13.9 \\
\hline 60 & 8 & 22.2 & 36.1 \\
\hline 61 & 10 & 27.8 & 63.9 \\
\hline 62 & 8 & 22.2 & 86.1 \\
\hline 63 & 3 & 8.3 & 94.4 \\
\hline 64 & 2 & 5.6 & 100.0 \\
\hline
\end{tabular}

Nilai tertinggi kesiapan pulang setelah diberikan metode video pada pasien dengan penyakit jantung koroner yaitu 2 orang respon den mendapatkan 64 dan nilai terendah setelah diberikan edukasi metode video sebanyak 2 responden dengan 58 .

Perbedaan Nilai Kesiapan Pulang pasien dengan Menggunakan Edukasi Ceramah dan Video

Tabel 9

Perbedaan Nilai Kesiapan Pulang Pasien dengan Menggunakan Edukasi Ceramah dan Video

\begin{tabular}{|c|c|c|c|c|}
\hline & \multicolumn{3}{|c|}{ Kelompok } & \multirow[b]{2}{*}{ Tota } \\
\hline & $\mathrm{N}$ & Ceramah & Video & \\
\hline \multirow{18}{*}{$\begin{array}{l}\text { Perbedaan Nilai } \\
\text { Sebelum } \\
\text { dan Sesudah }\end{array}$} & 2 & 2 & 0 & 2 \\
\hline & 3 & 1 & 0 & 1 \\
\hline & 4 & 2 & 0 & 2 \\
\hline & 5 & 7 & 0 & 7 \\
\hline & 6 & 5 & 0 & 5 \\
\hline & 7 & 6 & 0 & 6 \\
\hline & 8 & 7 & 0 & 7 \\
\hline & 9 & 3 & 0 & 3 \\
\hline & 10 & 1 & 1 & 2 \\
\hline & 11 & 1 & 3 & 4 \\
\hline & 12 & 1 & 4 & 5 \\
\hline & 13 & 0 & 7 & 7 \\
\hline & 14 & 0 & 5 & 5 \\
\hline & 15 & 0 & 5 & 5 \\
\hline & 16 & 0 & 5 & 5 \\
\hline & 17 & 0 & 3 & 3 \\
\hline & 18 & 0 & 2 & 2 \\
\hline & 20 & 0 & 1 & 1 \\
\hline Total & & 36 & 36 & 72 \\
\hline
\end{tabular}

Terlihat pada tabel diatas, perbedaan nilai pre dan post pada kelompok perlakuan yaitu 20, sedangkan pada kelompok kontrol nilai tertinggi adalah 12 . 


\section{Vol. 16 No.2 Mei - Agustus 2021}

\section{Pengaruh Menggunakan Edukasi Ceramah terhadap Kesiapan Pulang Pasien Dengan Penyakit Jantung Koroner}

Berdasarkan hasil uji normalitas data dengan ShapiroWilk, terlihat sebaran data pada kelompok informasi dengan metode ceramah (kelompok kontrol) berdistribusi normal, yaitu $P$-value $>0.05$ sehingga menggunakan uji parametrik untuk analisis menggunakan Paired simple t test.

Tabel 10

Uji Paired simple t test

\begin{tabular}{lc} 
& $P$-value \\
\hline $\begin{array}{l}\text { Sebelum dan setelah diberikan } \\
\text { informasi media ceramah }\end{array}$ & .000 \\
\hline
\end{tabular}

Berdasarkan uji Paired Simple-T Test dengan tingkat kepercayaan $95 \%$ didapatkan hasil $P$-value, $<0.005$ sehingga, ada pengaruh pemberian infomasi media ceramah terhadap kesiapan pasien pulang pada pasien dengan penyakit jantung koroner.

Pengaruh Menggunakan Edukasi Video terhadap Kesiapan Pulang Pasien Dengan Penyakit Jantung Koroner

Berdasarkan hasil uji normalitas data dengan ShapiroWilk, terlihat tsebaran data pada kelompok informasi dengan metode video (kelompok perlakuan) berdistribusi normal, yaitu $P$-value $>0.05$ sehingga untuk analisis menggunakan Paired simple t test.

Tabel 11

Tabel uji Paired simple t test

\begin{tabular}{lc}
\hline $\begin{array}{l}\text { Sebelum dan setelah diberikan informasi } \\
\text { media video }\end{array}$ & .000 \\
\hline
\end{tabular}

Berdasarkan uji Paired Simple-T Test dengan tingkat kepercayaan $95 \%$ didapatkan hasil P-value, <0.005 sehingga, ada pengaruh pemberian infomasi media video terhadap kesiapan pasien pulang pada pasien dengan penyakit jantung koroner.

\section{Analisis Perbedaan Pemberian Edukasi Ceramah dan Video terhadap Kesiapan Pulang Pasien dengan Penyakit Jantung Koroner}

Berdasarkan hasil uji normalitas data dengan Kolmogorov- Smirnov, terlihat sebaran data pada kelompok informasi dengan metode video (kelompok perlakuan) tidak berdistribusi normal, yaitu $P$ value $<0.05$ sehingga menggunakan uji non parametric untuk analisis menggunakan Mann-Whitney $U$.

Tabel 12

\begin{tabular}{lc} 
Uji Mann-Whitney $U$ & \\
\hline $\begin{array}{l}\text { Perbedaan Nilai Sebelum dan Sesudah } \\
\text { diberikan media }\end{array}$ & P-value \\
\hline $\begin{array}{l}\text { video dan ceramah } \\
Z\end{array}$ & .000 \\
\hline
\end{tabular}

Berdasarkan uji Mann-Whitney $U$ dengan tingkat kepercayaan $95 \%$ didapatkan hasil P-value, $<0.005$ sehingga, H0 ditolak yang berarti ada perbedaan pemberian edukasi cermah dengan edukasi video terhadap kesiapan pulang pasien dengan penyakit jantung koroner dengan nilai $\mathrm{Z}=$ -7.215 .

\section{PEMBAHASAN}

Pengaruh Edukasi Metode Ceramah terhadap Kesiapan Pulang Pasien dengan Penyakit Jantung Koroner

Dalam penelitian ini terlihat bahwa sebelum edukasi metode ceramah rata-rata nilai kesiapan pasien pulang adalah 47.72, selanjutnya setelah diberikan edukasi metode ceramah menjadi 54.33. Hasil uji statistik menunjukkan adanya pengaruh edukasi metode ceramah terhadap kesiapan pulang pasien dengan penyakit jantung koroner $(\mathrm{Z}=-17.464, P$-value $=0.00$ ).

Kesiapan pasien pulang adalah kemampuan dalam pengetahuan, pengalaman, dan keterampilan yang dimiliki seorang ataupun kelompok untuk melakukan kegiatan atau tugas tertentu serta keinginan seseorang yang berkaitan dengan keyakinan, komitmen, dan motivasi untuk menyelesaikan tugas atau kegiatan tertentu. Kesiapan merupakan kombinasi dari kemampuan dan keinginan yang berbeda yang ditunjukkan seseorang pada tiaptiap tugas yang diberikan (Serawati, 2017). Sedangkan menurut Kosobucka et al., (2018) kesiapan untuk dikeluarkan dari rumah sakit adalah konsep telah digambarkan sebagai perkiraan pasien dan anggota keluarga kemampuan untuk meninggalkan fasilitas perawatan aku. Dengan demikian maka, kesiapan pasien menghadapi pemulangan adalah kemampuan yang mencakup pengetahuan, pengalaman, dan keterampilan serta keinginan yang mencakup keyakinan, komitmen, dan motivasi pasien pasca bedah akut abdomen untuk melakukan aktifitas atau kegiatan yang diajarkan serta dianjurkan oleh perawat dan klinisi.

Pelaksanaan pendidikan kesehatan adalah suatu proses pembelajaran yang dilakukan kepada individu, keluarga, kelompok dan masyarakat yang dilakukan untuk merubah perilakunya yang tidak sehat ke pola yang lebih sehat. Proses pendidikan kesehatan ini 
melibatkan beberapa komponen, antara lain menggunakan strategi belajar mengajar, mempertahankan keputusan untuk membuat perubahan tindakan atau perilaku dan pendidikan kesehatan berfokus kepada perubahan perilaku untuk meningkatkan status kesehatan mereka (Notoatmodjo, 2007). Salah satu metode pendidikan kesehatan yang sering di lakukan di rumah sakit yaitu pemberian pendidikan kesehatan dengan metode ceramah. Metode ceramah merupakan penyampaikan sebuah materi informasi/pembelajaran dengan cara penuturan lisan kepada orang banyak.

Pengertian ini mengarahkan bahwa metode ceramah menekankan pada sebuah pemberian materi pembelajaran dengan cara penuturan lisan. Lisan dijadikan sebagai alat utama dalam menggunakan metode ceramah untuk mengajarkan sebuah materi pembelajara pada orang banyak. Bila proses penyampaian itu yang diandalkan oleh pemberi ceramah adalah penuturan lisan, maka pemberi ceramah harus betul-betul memperhatikan kemampuan suara dan tekniknya dalam penggunaan metode ceramah ini (Tarbiyah, 2014).

Terdapat beberapa dampak dari pemberian edukasi dengan metode ceramah terhadap kesiapan pasien pulang pada penyakit jantung koroner, yaitu meningkatkan pengetahuan pasien tentang tanda gejela dan hal hal yang penting dalam perawatan dirumah dengan penyakit jantung koroner, dengan meningkatkan pengetahuan pasien tentang penyakit jantung koroner sehingga pasien sudah siap dengan perawatan pasien pasca pulang dari rumah sakit. Pendapat ini didukung oleh Suprapti, (2017) yang mengatakan bahwa keberhasilan peningkatan pengetahuan pada pasien $T B$ paru disebabkan oleh metode yang digunakan dalam memberikan pengetahuan pada pasien, yaitu metode ceramah dengan materi yang tidak terlalu banyak serta materi pendidikan yang hanya sedikit dan sederhana akan lebih mudah dipahami dibandingkan materi pendidikan yang terlalu banyak.

Penyampaian discharge planning dengan metode ceramah mempunyai dampak terhadap kenaikan nilai kesiapan pasien dalam adaptasi pulang dan koping terhadap stress. Kesiapan pasien pada kelompok yang diberikan dalam menghadapi pemulangan yang lebih tinggi pada discharge planning dengan metode ceramah pada penelitian ini salah satunya disebabkan karena usia pasien yang sudah matang sehingga mudah dalam menimbulkan perubahan perilaku (Suprapti, 2017).

Hasil penelitian ini sama dengan penelitian yang dilakukan Kriswanto, (2016), Tujuan dari penelitian ini untuk melihat pengaruh discharge planning terhadap kesiapan pasien pulang pada pasien di ruang unit stroke RSUD dr Soedono Madiun. Jenis peneilitian quasy ekperiment dengan desain penelitian "pre-post test control-group desaign" tehnik pengambilan sampel "purposive" sebanyak 30 orang dibagi menjadi kelompok perlakuan 15 dan kelompok kontrol 15. Pre tes sebelum perlakuan dan post tes setelah perlakuan dengan, dan untuk melihat pengaruh discharge planning dianalisa dengan uji Wilcoxon Sign Rank dan untuk melihat perbedaan antara kedua kelompok digunakan U Mann-witney dengan nilai $\alpha=$ 0,05 Hasil uji Wilxoxon pada kelompok perlakuan didapatkan hasil $\mathrm{P}=0,001<(\alpha=0,05)$ ada pengaruh discharge planning dan pada kelompok kontrol $P=$ $0,139<(\alpha=0,05)$.

Dengan pemberian discharge planning metode ceramah di awal masuk rumah sakit, selama perawatan dan menjelang keluar rumah sakit berupa leaflet, ceramah dan tanya jawab menjadikan stimulus positif sehingga mampu meningkatkan pengetahuan, keyakinan, ketrampilan dan motivasi kepada pasien untuk meningkatkan dan mempertahankan status kesehatan pasien. Perlunya mengukur kesiapan pasien pulang yang dilakukan untuk memastikan kemampuan pasien dari berbagai segi aspek biopsikospiritual bukan hanya dari fisik.

\section{Pengaruh Edukasi Metode Video terhadap Kesiapan Pulang Pasien dengan Penyakit Jantung Koroner}

Dalam penelitian ini terlihat bahwa sebelum edukasi metode video, rata-rata nilai kesiapan pasien pulang adalah 46.72, selanjutnya setelah diberikan edukasi metode video menjadi 61.00 Hasil uji statistik menunjukkan adanya pengaruh edukasi metode ceramah terhadap kesiapan pulang pasien dengan penyakit jantung koroner $(\mathrm{Z}=-37.442$, P-value $=$ 0.000).

Setelah menjalani perawatan di rumah sakit dan pasien dengan penyakit jantung koroner dalam kondisi terkontrol, maka pasien diupayakan secara bertahap untuk kembali ke aktivitas seperti sebelum sakit sedini mungkin. Aktivitas kegiatan hidup sehari hari harus direncanakan untuk meminimalkan timbulnya gejala yang diakibatkan kelelahan, dan setiap aktivitas yang dapat menimbulkan gejala harus dihindari atau dilakukan adaptasi. Berbagai penyesuain kebiasaan pekerjaan dan hubungan interpersonal harus dilakukan. Pasien harus dibantu untuk mengidentifikasi stres emosional dan menggali cara cara untuk menyelesaikannya. Pasien yang dating ke klinik atau rumah sakit biasanya diakibatkan adanya serangan jantung berulang. Kebanyakan serangan berulang dan dirawat kembali di rumah sakit terjadi karena ketidakmanpuan secara ekonomi. Pasien sering kembali melaksanakan terapi pengobatan yang kurang tepat, melanggar pembatasan diet, tidak mematuhi tindak lanjut medis, melakukan aktivitas fisik yang berlebihan dan tidak mengetahui gejala kekambuhan (Smeltzer, S.C. \& Bare, 2012).

Informasi yang optimal dapat diperoleh oleh pasien dan keluarga melalui supportive educational system dalam proses persiapan pasien pulang yang diberikan oleh perawat. Media pembelajaran yang efektif dapat difasilitasi dengan metode yang 


\section{Vol. 16 No.2 Mei - Agustus 2021}

mengkombinasikan komponen visual, audio dan animasi. Melalui media audio dan visual seseorang dapat dengan mudah memahami informasi yang didapatkan karena sebagian besar pengetahuan diperoleh melalui mata dan telinga (Zuraida.S, 2018). Video dapat mengilustrasikan sesuatu yang terjadi dalam kehidupan nyata yang mempengaruhi motivasi seseorang memahami suatu materi, selain itu kemampuan modifikasi tambahan seperti animasi, suara dan elemen lain yang tersedia di media video membuatnya jauh lebih menarik dari pada pendidikan edukasi melalui media lainnya (Rakhmilla., Larasati., \& Sahiratmadja, 2017).

Menurut Zuraida S, (2018) pemberian edukasi kepada pasien melalui video dapat memberikan deep learning kepada pasien, menghemat waktu dan lebih efektif. Hal ini sejalan dengan apa yang di sebutkan oleh Tuong, W., (2012) Intervensi pendidikan berbasis video telah digunakan untuk penyakit kronis lainnya untuk meningkatkan pengetahuan dan meningkatkan perilaku kesehatan. Video pendidikan terbukti lebih efektif daripada bahan tertulis untuk meningkatkan pengetahuan dan modifikasi perilaku kesehatan. Hasil penelitian Denny, (2017) juga menunjukkan penggunaan video untuk memberikan edukasi terbukti dapat meningkatkan pengetahuan, self-efficacy dalam mengenali gejala serangan jantung, dan meningkatkan kepuasan pasien jantung mengenai edukasi yang diberikan rumah sakit sebelum mereka pulang.

Hasil penelitian ini juga membuktikan peran perawat penting untuk dapat melakukan intervensi keperawatan dalam bentuk edukasi dalam proses mempersiapkan kesiapan pasien pulang. Dalam kerangka teori keperawatan self care Orem, pasien di posisikan sebagai pihak yang mengalami peningkatan kebutuhan perawatan diri dan agen keperawatan mempunyai peran dalam membantu pasien untuk memenuhi kebutuhan tersebut, bentuk bantuan perawat terdiri dari bantuan perawatan diri secara total, parsial dan supportive educative system. Pada saat pasien berada di rumah sakit perawat dapat berperan sebagai agen perawatan diri bagi pasien untuk membantu memenuhi kebutuhan parsial atau total, namun saat pasien direncanakan pulang maka perawat harus memberikan support edukasi kepada keluarga yang nantinya akan menjadi agen perawatan bagi pasien saat berada di rumah (Alligood, 2014). Support edukasi ini efektif dilakukan oleh perawat, didasarkan hasil penelitian Denny, (2017) yang menyatakan intervensi keperawatan dalam bentuk suportif-edukatif dapat meningkatkan kemampuan perawatan diri pada keluarga dan pasien.

Selain penggunaan media yang baik, keberhasilan pelaksanaan kesiapan pasien pulang yang pada saat edukasinya menggunakan video ini juga terletak pada pelaksanaan edukasi yang dilakukan tidak hanya sekali pertemuan saja, menurut Siti Zuraida Muhsinin, (2018) frekuensi edukasi yang dilakukan lebih dari sekali tindakan dalam proses perencanaan pemulangan lebih efektif, sehingga memastikan transisi dari rumah sakit ke rumah lebih aman. Dalam penelitian ini peneliti melakukan 3 kali pertemuan untuk proses edukasi, untuk pertemuan pertama diberikan pada saat pasien diberikan untuk pindah dari ruang intensive cardiac care unit. Materi yang diberikan tentang pengertian, jenis-jenis penyakit jantung koroner, tanda gejala, faktor resiko, pencegahan dan pertolongan pertama pada pasien serangan jantung. Selanjutnya diberikan informasi yang sama di ruang rawat inap biasa seperti ruang Kecak dan Janger sampai pasien di ijinkan untuk pulang.

Pasien yang memahami dengan jelas rencana kesiapan pulang mereka termasuk caranya untuk mengatur waktu untuk mengkomsumsi obat-obatan mereka dan kapan harus melakukan tindak lanjut, 30\% lebih kecil kemungkinannya untuk kembali atau mengunjungi departemen darurat daripada pasien yang kekurangan informasi (Jack, 2009).

Media yang baik dan frekuensi pelaksanaan edukasi yang tidak hanya sekali tidak akan efektif jika kemampuan responden memahami informasi yang diberikan tidak baik, hal yang dapat mempengaruhi kemampuan responden memahami informasi dan mempunyai kompetensi dalam melakukan perawatan adalah faktor usia dan tingkat pendidikan. Menurut Zuraida.S, (2018) seseorang dengan tingkat pendidikan rendah dan usia yang lebih tua memiliki kemampuan yang rendah untuk menerima suatu informasi, hal tersebut dikaitkan dengan ketidakmampuannya menyebutkan kembali informasi terkait faktor resiko terjadinya kekambuhan pada penyakit jantung koroner.

\section{Analisis Pengaruh Edukasi Metode Ceramah dengan Video terhadap Kesiapan Pulang Pasien dengan Penyakit Jantung Koroner}

Hasil penelitian menunjukkan rata-rata nilai kesiapan pasien pulang post test-pre test pada kelompok perlakuan lebih besar dibandingkan rata-rata nilai kesiapan pasien pulang post test - pre test pada kelompok kontrol. Hasil uji statistik menunjukkan pemberian edukasi media video memiliki pengaruh yang lebih besar dibandingkan dengan pemberian edukasi media ceramag terhadap kesiapan pasien pulang pasien dengan penyakit jantung koroner $(\mathrm{p}=0,000)$.

Ketidaksiapan pasien untuk pulang pasca dirawat di rumah sakit salah satunya akan berdampak pada resiko dirawat kembali mejadi meningkat, ini disebakan karena ketidakmampuan pasien dalam perawatan diri dirumah, pemenuhan gizi yang salah, jadwal minum obat yang keliru dan aktivitas aktivitas yang boleh dan tidak boleh di lakukan pasca dirawat dirumah sakit. Pendapat ini didukung oleh (Desai \& Stevenson, 2012), pasien dengan penyakit jantung 
koroner masuk rawat inap kembali ke rumah sakit dalam waktu enam bulan setelah pulang dari rumah sakit, salah satu faktor yang mempengaruhinya adalah menurunnya ketaatan terapi dan kurangnya informasi kesehatan yang diperoleh pasien serta kurang maximalnya pemberian asuhan keperawatan yang diberikan untuk mempersiapkan pasien pulang.

Pendidikan kesehatan kepada pasien didefinisikan sebagai proses yang diberikan oleh profesional kesehatan dalam memberikan informasi kepada pasien bertujuan untuk mengubah perilaku kesehatan atau meningkatkan status kesehatan. Program pendidikan manajemen diri dirancang untuk memungkinkan orang dengan kondisi kronis untuk berperan aktif dalam mengelola kondisinya sendiri. Program ini adalah intervensi perilaku kompleks yang menargetkan pendidikan pasien dan mempromosikan perilaku perawatan diri dan faktor risiko termodifikasi dan bertujuan untuk meningkatkan status kesehatan dan menurunkan kejadian komplikasi bagi pasien yang menyebabkan berkurangnya rawat inap dan pengurangan biaya perawatan, baik untuk pasien maupun sistem perawatan kesehatan (Anderson et al., 2017).

Pendidikan kesehatan merupakan komponen penting dari program komprehensif rehabilitasi jantung dan memberikan rekomendasi Kelas I. bahwa pasien dengan sindrom koroner akut non-ST-elevasi (PJK) dan individu dengan risiko penyakit kardiovaskular yang sangat tinggi, harus dididik tentang manajemen kolesterol yang tepat, tekanan darah, berhenti merokok, dan manajemen gaya hidup. Intervensi pendidikan dalam perawatan jantung meningkatkan pengetahuan pasien dan memfasilitasi perubahan perilaku. Intervensi pendidikan dalam perawatan jantung telah terbukti meningkatkan aktivitas fisik, dan mengarah ke kebiasaan makan yang lebih sehat dan berhenti merokok, kepatuhan dalam pengobatan atau kesejahteraan psikososial lebih baik. Penyampaian program pendidikan pasien dapat bervariasi secara substansial, baik dalam bentuk ceramah dan demonstrasi serta secara audio visual berserta animasi (Anderson et al., 2017).

Media video adalah media yang menyajikan audio dan visual yang berisi pesan-pesan pembelajaran baik yang berisi konsep, prinsip, prosedur, teori aplikasi pengetahuan untuk membantu pemahaman terhadap suatu materi pembelajaran. Video merupakan bahan pembelajaran tampak dengar (audio visual) yang dapat digunakan untuk menyampaikan pesanpesan/materi pelajaran. Dikatakan tampak dengar kerena unsur dengar (audio) dan unsur visual/video (tampak) dapat disajikan serentak (Cheppy, 2007).

Metode promosi yang bisa digunakan untuk mempersiapkan pasien pulang yaitu dengan media audio visual, media ini merupakan salah satu media promosi kesehatan yang digunakan sebagai media pendidikan kesehatan dengan unsur gerak, suara dan gambar yang terpadu menjadi satu (Notoatmodjo, 2012b). Menurut Abu Abed, Himmel, Vormfelde, \&
Koschack, (2014), video mampu merebut 94\% saluran masuknya pesan atau informasi ke dalam jiwa manusia melalui mata dan telinga serta mampu untuk membuat orang pada umumnya mengingat $50 \%$ dari apa yang mereka lihat dan dengar dari tayangan program. Pesan yang disampaikan melalui media video dapat mempengaruhi emosi yang kuat dan juga dapat mencapai hasil cepat yang tidak dimiliki oleh media lain (Fiore-silfvast et al., 2013).

Dalam penelitian ini media video yang digunakan dengan durasi 6 menit. Media video diberikan dengan menggunakan ipad/table, hal ini sesuai dengan penelitian Brame, (2016), menurutnya keterlibatan penerima informasi merupakan hal yang penting, ada media video tanpa adanya yang menonton informasi yang diberikan tidak akan pernah sanpai. Media video tersampaikan $100 \%$ bila durasi yang diberikan kurang dari atau sama dengan 6 menit dan penerima informasi menyaksikan keseluruhan video. Brame juga mengatakan jika durasi ditingkatkan menjadi 9 - 12 ketertarikan penerima informasi turun menjadi 50\% dan jika durasi ditingkatkan menjadi 12 - 40 menit, ketertarikan penerima untuk menonton keseluruhan video menurun menjadi $20 \%$.

Teknologi dapat meningkatkan pembelajaran dan berbagai penelitian telah menunjukkan bahwa video khususnya, bisa menjadi sangat efektif sebagai alat pendidikan. Video mempunyai nilai khusus untuk persiapan peserta promosi kesehatan, sebagian karena peserta dapat merasa lebih menarik dan karena dapat sangat sesuai untuk penjelasan fenomena abstrak atau yang sulit untuk divisualisasikan yang menjadi fokus banyak orang. prinsip-prinsip yang memungkinkan pemberi materi untuk memilih atau mengembangkan video yang efektif salah satu emelen yang berperan penting adalah penting cognitive load (Brame, 2016).

\section{Gambar 1}

Proses Long Term Memory Pada Edukasi Media Video

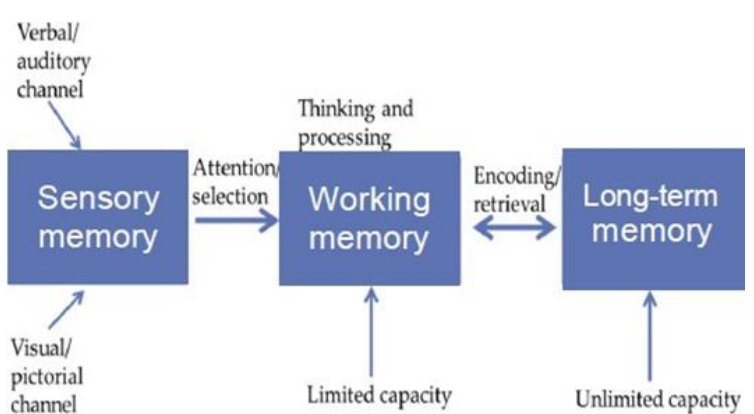

Based on Mayer (2003) and Mayer and Moreno (2007)

Menurut Brame, (2016) proses cognitive load dimulai dari peneriman channel verbal dan channel visual yang masuk ke dalam memori sensory, pada sensory kemudian masuk kedalam working memory berdasarkan pemilihan dan perhatian dimana disini timbul proses berpikir dan memproses sebuah informasi. Pada working memory kapasitas memori hanya terbatas, sehingga tidak semua informasi dapat 


\section{Vol. 16 No.2 Mei - Agustus 2021}

diingat dengan baik. Konteks visual dan verbal akan mampu diterima sampai di long term memory yang kapasitasnya tidak terbatas. Berdasarkan uraian tersebut penggunakan media video mampu bertahan lebih lama atau dikenal dengan resistensi informasi sehingga informasi yang disampaikan dengan format media audio visual, akan lebih lama disimpan didalam memori, sehingga dengan demikian pasien yang diberikan edukasi video mampu dan paham hal hal yang berkaitan dengan perawatan pasien dirumah pasca dirawat dirumah sakit seperti, pengaturan diet, jadwal minum obat, aktivitas yang boleh dilakukan, hal apa yang harus dilakukan jika terjadi serangan jantung, dan managemen stres. Inforrmasi yang diberikan lebih lama disimpan dalam memori akan membuat pasien siap untuk merawat diri dirumah sehingga bisa beraktifitas seperti biasa seperti sebelum dirawat dirumah sakit. Pendapat tersebut sesuai dengan penelitian Zuraida.S,(2018), Health education video project dalam proses discharge planning dapat meningkatan kesiapan keluarga dalam merawat pasien stroke di rumah, hal tersebut didasarkan pada hasil uji mann whitney dengan nilai $p$ value $(0,000)<\alpha(0,05)$.

Selain itu penelitian Tuong, (2012) mengatakan, media edukasi video dapat mengubah perilaku kesehatan. Dalam penelitian ini bertujuan untuk menguji efektivitas intervensi video dalam mengubah perilaku kesehatan. Dua puluh delapan studi yang terdiri dari 12.703 subjek dimasukkan dalam tinjauan penelitian ini. Intervensi video sangat efektif untuk memodifikasi perilaku kesehatan tergantung pada target perilaku yang akan dipengaruhi. Intervensi video tampaknya efektif dalam pemeriksaan payudara sendiri, skrining kanker prostat,, perawatan diri pada pasien gagal jantung, tes HIV, kepatuhan pengobatan,. Selain itu, video dapat memfasilitasi pembelajaran perilaku baru dan dapat menjadi pertimbangan penting dalam intervensi video di masa mendatang.

\section{KESIMPULAN}

Hasil uji statistik menunjukkan adanya pengaruh edukasi metode ceramah terhadap kesiapan pulang pasien dengan penyakit jantung koroner $(\mathrm{Z}=$ 17.464, $P$-value $=0.00)$. Terdapat beberapa dampak dari pemberian edukasi dengan metode cermah terhadap kesiapan pasien pulang pada penyakit jantung koroner, yaitu meningkatkan pengetahuan pasien tentang tanda gejala dan hal hal yang penting dalam perawatan dirumah dengan penyakit jantung coroner.

Hasil uji statistik menunjukkan adanya pengaruh edukasi metode video terhadap kesiapan pulang pasien dengan penyakit jantung koroner $(\mathrm{Z}=$ 37.442, P-value $=0.000)$. Media video dapat mengilustrasikan sesuatu yang terjadi dalam kehidupan nyata yang mempengaruhi motivasi seseorang memahami suatu materi, selain itu kemampuan modifikasi tambahan seperti animasi, suara dan elemen lain yang tersedia di media video membuatnya jauh lebih menarik dari pada pendidikan melalui media lainnya.

Hasil uji statistik menunjukkan pemberian edukasi media video memiliki pengaruh yang lebih besar dibandingkan dengan pemberian edukasi media ceramah terhadap kesiapan pasien pulang pasien dengan penyakit jantung koroner $(\mathrm{p}=0,000)$. Media video mampu merebut $94 \%$ saluran masuknya pesan atau informasi ke dalam jiwa manusia melalui mata dan telinga serta mampu untuk membuat orang pada umumnya mengingat $50 \%$ dari apa yang mereka lihat dan dengar dari tayangan program.

Bagi bidang keperawatan yang memberikan pendidikan kesehatan, diharapkan mampu mengembangkan dan mengaplikasikan metode promosi kesehatan dengan media video khususnya pada pasien dengan penyakit jantung koroner.

\section{DAFTAR PUSTAKA}

1. Abu Abed, M., Himmel, W., Vormfelde, S., \& Koschack, J. (2014). Video- assisted patient education to modify behavior: A systematic review.

Patient Education and Counseling, 97(1), 16-22. https://doi.org/10.1016/j.pec.2014.06.015

2. Alfridsyah, Hadi, A., \& I. (2017). Faktor Risiko Terjadinya Penyakit Jantung Koroner Pada Pasien Rumah Sakit Umum Meuraxa Banda Aceh. Jurnal Action : Aceh Nutrition Journal, 2, 2, 32-42.

3. Alligood, \& T. (2014). Nursing Theory: Utilization and Application 8rd edition. ST. Louis: Mosby Elsevier, Inc.

4. Aminita Putri, R., Yuda Mindara, J., \& Suryaningsih, S. (2017). Rancang Bangun Wireless Elektrokardiogram (Ekg). Jurnal Ilmu Dan Inovasi Fisika, 1(1), 58-64. https://doi.org/10.24198/jiif.v1n1.8

5. Anderson, L., Jpr, B., Am, C., Dalal, H., Hkk, R., Bridges, C., ... Rs, T. (2017). Patient education in the management of coronary heart disease (Review). https://doi.org/10.1002/14651858.CD008895.pub3 .www.cochranelibrary.com

6. Arikunto. (2016). Prosedur Penelitian: Suatu Pendekatan Praktik. Jakarta: Rineka Cipta. 
7. Arsyad, A. (2011). Media Pembelajaran. jakarta: PT Raja Grafindo Persada.

8. B. Mulyadi, P. (2006). Clinical Pathology and Majalah Patologi Klinik Indonesia dan Laboratorium Medik. Jurnal Indonesia, 21(3), 261-265.

9. Batubara, H. H., \& Ariani, D. N. (2016). Pemanfaatan Video sebagai Media Pembelajaran Matematika SD/MI. Muallimuna: Jurnal Madrasah Ibtidaiyah, 2(1), 47. https://doi.org/10.31602/muallimuna.v2i1.741

10. Brame, C. J. (2016). Effective educational videos: Principles and guidelines for maximizing student learning from video content. CBE Life Sciences Education, 15(4), es6.1-es6.6. https://doi.org/10.1187/cbe.16-03-0125

11. Buszko, K., Kosobucka, A., Michalski, P., Pietrzykowski, Ł., Jurek, A., Wawrzyniak, M., ... Kubica, A. (2017). The readiness for hospital discharge of patients after acute myocardial infarction: a new self-reported questionnaire. Medical Research Journal, 2(1), 20-28. https://doi.org/10.5603/mrj.2017.0004

12. Carpenito Lynda juall. (1999). Rencana Asuhan Keperawatan dan Dokumentasi Keperawatan (2nd ed.). Jakarta: EGC.

13. Cheppy, R. (2007). Pedoman Pengembangan Media Video. Bandung: Program P3AI Universitas Pendidikan Indonesia.

14. Cleeman, J. I. (2001). Executive summary of the third report of the National Cholesterol Education Program (NCEP) expert panel on detection, evaluation, and treatment of high blood cholesterol in adults (adult treatment panel III). Journal of the American Medical Association, 285(19), 24862497. https://doi.org/10.1001/jama.285.19.2486

15. Corwin, E. J. (2009). buku Saku Patofisiologi. jakarta: Penerbit buku kedokteran EGC.

16. Dahlan. (2011). Statistik untuk kedokteran dan kesehatan. Jakarta: Salemba Medika.

17. Denny. (2017). Video-Based Educational Intervention Associated With Improved Stroke Literacy, Self- Efficacy, and Patient Satisfaction.

18. Desai, \& Stevenson. (2012). Rehospitalization for heart failure: Predict or prevent? Circulation, 126(4), 501-506. https://doi.org/10.1161/CIRCULATIONAHA.112. 125435

19. Fakultas Kedokteran Universitas Hasanuddin. (2017). Buku Acuan Peserta CSL 2. 1-17.

20. Fiore-silfvast, B., Fiore-silfvast, B., Hartung, C., Iyengar, K., Iyengar, S., Israel- ballard, K., ...
Anderson, R. (2013). Mobile video for patient education: The midwives 'perspective Mobile video for patient education: The midwives , perspective. (January

2014). https://doi.org/10.1145/2442882.2442885

21. Fitri, E. Y., Andini, D., \& Natosba, J. (2020). Pengaruh Discharge Planning Model LIMA terhadap Kesiapan Pulang pada Pasien dengan Diabetes Melitus. Jurnal Kepemimpinan Dan Manajemen Keperawatan, 3(1), 15. https://doi.org/10.32584/jkmk.v3i1.443

22. H Bagheri, M., R Memarian, M., \& F Alhani, P. (2007). Evaluation of the effect of group counselling on post myocardial infarction patients: determined by an analysis of quality of life.

23. Hardianti, H., \& Asri, W. K. (2017). Keefektifan Penggunaan Media Video Dalam Keterampilan Menulis Karangan Sederhana Bahasa Jerman Siswa Kelas Xii Ipa Sma Negeri 11 Makassar. Eralingua: Jurnal Pendidikan Bahasa Asing Dan Sastra, 1(2), 123-130. https://doi.org/10.26858/eralingua.v1i2.4408

24. Hasan. (2016). Penyakit Jantung Koroner. From Smart Patient.

25. Jack, B. W. (2009). Taking the Time to Care: Empowering Low Health Literacy Hospital Patients with Virtual Nurse Agents. 1265-1274.

26. Juzar D, I. (2015). Sindrom Koroner Akut (Santoso K, ed.). jakarta: Badan Penerbit FKUI.

27. Kaplan, M.D., \& Stemler, M. . (1991). Pencegahan Penyakit Jantung Koroner. jakarta: Penerbit buku kedokteran EGC.

28. Kementrian Kesehatan RI. (2011). Pedoman Pembinaan Perilaku Hidup Bersih dan Sehat. jakarta: Kementerian Kesehatan.

29. Kosobucka, A., Kasprzak, M., Michalski, P., Pietrzykowski, Ł., Fabiszak, T., Felsmann, M., \& Kubica, A. (2018). Relation of the Readiness for Hospital Discharge after Myocardial Infarction Scale to socio-demographic and clinical factors. An observational study. Medical Research Journal, $3(1), \quad 32-\quad 37$. https://doi.org/10.5603/mrj.2018.0006

30. Kriswanto. (2016). Pengaruh Discharge Planning Terhadap Kesiapan Pasien Pulang Pada Pasien Stroke Dengan Menggunakan Rhds (Readiness Of Hospital Discharge Scale) Di Ruang Unit Stroke Rsud Dr. Soedono Madiun.

31. Kurniadi dan Nurrahmani. (2014). Stop Diabetes, Hipertesi, Kolestrol Tinggi, Jantung Koroner. Yogyakarta: Istana Media. 


\section{Vol. 16 No.2 Mei - Agustus 2021}

32. Min, D. I., \& Cirebon, K. (2016). Akhmad Busyaeri, Tamsik Udin, A. Zaenudin, Pengaruh Penggunaan Video. 3(20), 116-137.

33. Notoatmodjo. (2007). Pendidikan Kesehatan dan Perilaku Kesehatan. jakarta: Rineka Cipta.

34. Notoatmodjo. (2012a). Metodologi Penelitian Kesehatan. jakarta: Rineka Cipta. Notoatmodjo. (2012b). Promosi Kesehatan dan Perilaku Kesehatan. Jakarta: PT Rineka \Cipta.

35. Nursalam. (2013). Metodelogi Penelitian Ilmu Keperawatan: Pendekatan praktis. jakarta: Salemba Medika.

36. Orem, D. (2001). Nursing Concept of Pratice. St Louis: The C.V. Mosby Company.

37. Perhimpunan Dokter Spesialis Kardiovaskular Indonesia. (2016). Pedoman Uji Latih Jantung: Prosedur dan Interpretasi.

38. PERKI. (2019). Panduan Tatalaksana Angina Pekoris Stabil.

39. Potter, D, \& Perry, A. (2005). Buku Ajar: Fundamental keperawatan, konsep, proses dan praktik (4th ed.). jakarta: EGC.

40. Rakhmilla, L. E., Larasati, R., \& Sahiratmadja, E. K. (2017). Assessing Knowledge About Thalassemia Among Reproductive Age Population After Video Media Education. Journal of Biomedical and Clinical Science, 2, 30- 32.

41. Rofi'i. (2013). Faktor Personil Dalam Pelaksanaan Discharge Planning. Jurnal Managemen Keperawatan, 1(2), 89-94.

42. RSD Mangusada, 2018. (2018). Buku Profil RSD Mangusada.

43. Sastroasmoro. (2010). Dasar-Dasar Metodologi Penelitian Klinis edisi ketiga. In: Pemilihan Subyek Penelitian dan Desain Penelitian (3rd ed.). Jakarta: Sagung Seto.

44. Serawati. (2017). Pengaruh Perencanaan Pulang Terhadap Persiapan Pasien Pulang Pada Pasien Ibu Nifas Di Rs panti Wilaysa Citarum Semarang. Journal of Chemical Information and Modeling, 53(9), 1689-1699. https://doi.org/10.1017/CBO9781107415324.004

45. Siti Damawiyah. (2015). Pengaruh Penerapan Discharge Planningdengan Pendekatanfamily Centered Nursingterhadap Motivasi Dan Kesiapankeluargadalam Merawat Pasien Stroke Pasca Akut Di Rs. Islam Surabaya. World Agriculture, 1(May), 1-9. https://doi.org/10.1017/CBO9781107415324.004
46. Slameto. (2013). Belajar dan faktor - faktor yang mempengaruhinya. Jakarta: PT Rineka Cipta.

47. Smeltzer, S.C. \& Bare, B. . (2012). ). Buku Ajar Keperawatan Medikal Bedah Brunner \& Suddarth (8th ed.). yogyakarta: EGC.

48. Soeharto Iman. (2001). Pencegahan Dan Penyembuhan Penyakit Jantung Koroner Panduan Bagi Masyarakat Umum. Jakarta: Gramedia Pustaka.

49. Sugiyono. (2012). Metode Penelitian Kuantitatif Kualitatif dan R\&D. Bandung: Alfabeta.

50. Sugiyono. (2016). Metode Penelitian Pendidikan Pendekatan Kuantitatif, Kualitatif, dan R\&D. Bandung: : Alfabeta.

51. Sugiyono. (2017). Metode Penelitian Kuantitatif, Kualitatif, dan $R \& D$. Bandung: Alfabeta.

52. Suprapti, E. (2017). Pengaruh Discharge Planning Terstruktur Untuk Meningkatkan Kesiapan Pasien Tb Paru Menghadapi Pemulangan ( Studi Eksperimental Di Rsud Tugurejo Dan Rsud Kota Semarang ) Pendahuluan. 1-8.

53. Susalit, Kapojos EJ, L. H. (2001). Buku Ajar Ilmu Penyakit Dalam, Jilid II, Edisi Ketiga, (V). Jakarta: nterna Publishing;

54. Susanti, nirman. (2017). Promosi dan pendidikan kesehatan. jakarta: Trans info media.

55. Tarbiyah, J. (2014). Metode Ceramah: Konsep Dan Aplikasi Dalam Pembelajaran Pendidikan Agama Islam. 21(2), 375-401.

56. Tuong, W. (2012). Videos to Influence: A Systematic Review of Effectiveness of VideoBased Education in Modifying Health Behaviors. Journal of Behavioral Medicine.

57. Wahyuni, A., Nurrachmah, E., \& Gayatri, D. (2012). Kesiapan pulang Pasien Penyakit Jantung Koroner Melalui Penerapan Discharge Planning. Jurnal Keperawatan Indonesia, 15(3), 151-158. https://doi.org/10.7454/jki.v15i3.3

58. WHO. (2013). About Cardiovascular diseases.

59. Widyantari, N. P. S., Wijaya I. P. A., \& Susila, I M. D. P. (2019). Hubungan Tingkat Pengetahuan Tentang Menopause Dengan Kecemasan Menghadapi Menopause Pada Ibu Pembinaan Kesejahteraan Keluarga. Journal Center of Research Publication in Midwifery and Nursing, 3 (2), 56-59

60. Yudianto, A. (2017). Penerapan Video Sebagai Media Pembelajaran. Seminar Nasional Pendidikan 2017, 234-237. 
61. Zahrawardani, D., Herlambang, K. S., \& Anggraheny, H. D. (2013). Analisis Faktor Risiko Kejadian Penyakit Jantung Koroner di RSUP Dr Kariadi Semarang. Jurnal Kedokteran Muhammadiyah, l(3), 13.
62.Zuraida.S. (2018). Discharge Planning Untuk Meningkatan Kesiapan Keluarga Dalam Merawat Pasien Stroke Di Rsud Kota Mataram. 